Int. J. Dev. Biol. 52: 1033-1042 (2008)

doi: $10.1387 / \mathrm{ijdb} .082663 \mathrm{jd}$

\title{
Genetic and epigenetic instability of human bone marrow mesenchymal stem cells expanded in autologous serum or fetal bovine serum
}

\author{
JOHN-ARNE DAHL ${ }^{1, \#, ~ S H I V A L I ~ D U G G A L ~ 2, \#, ~ N E R A L I E ~ C O U L S T O N ~}{ }^{3}$, DOUGLAS MILLAR ${ }^{3}$, JOHN MELKI ${ }^{3}$, \\ ABOULGHASSEM SHAHDADFAR ${ }^{2}$, JAN E. BRINCHMANN ${ }^{2}$ and PHILIPPE COLLAS ${ }^{1, *}$ \\ ${ }^{1}$ Department of Biochemistry, Institute of Basic Medical Sciences, Faculty of Medicine, University of Oslo, ${ }^{2}$ Institute of Immunology, \\ Rikshospitalet Medical Centre, Oslo, Norway and ${ }^{3}$ Human Genetic Signatures Ltd, North Ryde, Australia
}

\begin{abstract}
Culture of mesenchymal stem cells (MSCs) under conditions promoting proliferation and differentiation, while supporting genomic and epigenetic stability, is essential for therapeutic use. We report here the extent of genome-wide DNA gains and losses and of DNA methylation instability on 170 cancer-related promoters in bone marrow (BM) MSCs during culture to late passage in medium containing fetal bovine serum (FBS) or autologous serum (AS). Comparative genomic hybridization indicates that expansion of BMMSCs elicits primarily telomeric deletions in a subpopulation of cells, the extent of which varies between donors. However, late passage cultures in AS consistently display normal DNA copy numbers. Combined bisulfite restriction analysis and bisulfite sequencing show that although DNA methylation states are overall stable in culture, AS exhibits stronger propensity than FBS to maintain unmethylated states. Comparison of DNA methylation in BMMSCs with freshly isolated and cultured adipose stem cells (ASCs) also reveals that most genes unmethylated in both BMMSCs and ASCs in early passage are also unmethylated in uncultured ASCs. We conclude that (i) BMMSCs expanded in AS or FBS may display localized genetic alterations, (ii) AS tends to generate more consistent genomic backgrounds and DNA methylation patterns, and (iii) the unmethylated state of uncultured MSCs is more likely to be maintained in culture than the methylated state.
\end{abstract}

KEY WORDS: bisulfite sequencing, COBRA, genomic stability, comparative genomic hybridization

\section{Introduction}

The potential for in vitro expansion, differentiation and oncogenic transformation of mesenchymal stem cells (MSCs) has been extensively investigated primarily because of their potential use in cell therapy for tissue repair (Brooke et al., 2007) and as immunosuppressive vehicle (Le Blanc K. and Ringden, 2007). Bone marrow MSCs (BMMSCs) can differentiate into mesodermal lineages (Pittenger et al., 1999) and a small subpopulation seems to exhibit more extensive differentiation ability (Jiang et al., 2002). MSCs with mesodermal differentiation potential can also be obtained in large numbers from adipose tissue (Zuk et al., 2001; Boquest et al., 2005; Katz et al., 2005).
Using MSCs in a therapeutic context necessitates large-scale in vitro expansion, increasing the probability of genetic and epigenetic instabilities. Spontaneous oncogenic transformation commonly affects mouse MSCs (e.g., Miura et al., 2006; Tolar et al., 2007). However, reports of transformation of human MSCs are scarce. Most human MSC types cultured to late passages display normal karyotypes (Rubio et al., 2005; Miura et al., 2006; Zhang et al., 2007), genomic stability (Bernardo et al., 2007b), and absence of telomerase expression and activity (Bernardo et

Abbreviations used in this paper: AS, autologous serum; ASC, adipose stem cell; $\mathrm{BM}$, bone marrow; CGH, comparative genomic hybridization; FBS, fetal bovine serum; MSC, mesenchymal stem cell.

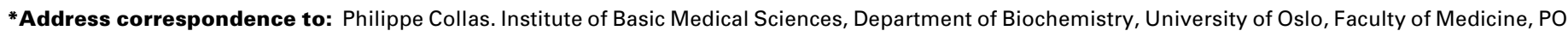
Box 1112 Blindern, 0317 Oslo, Norway. Phone: 47-22851066; Fax: 47-2285-1058. e-mail: philippe.collas@medisin.uio.no

\# Note: These authors contributed equally
}

Electronic Supplementary Material for this article consisting of 4 figures and 2 tables is available at: http://dx.doi.org/10.1387/ijdb.082663jd 


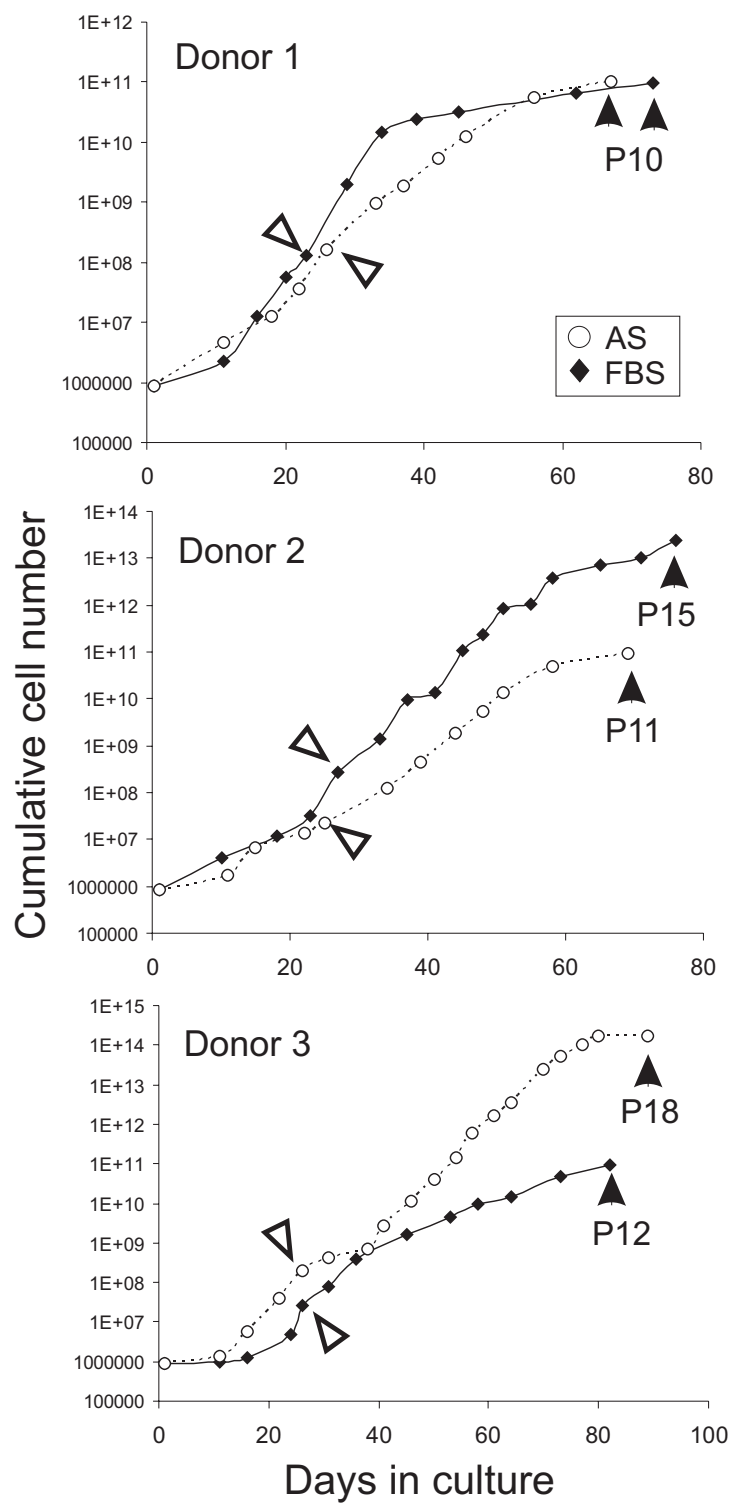

Fig. 1. Proliferation of human BMMSCs isolated from three donors and expanded in AS or FBS. White arrows point to P4, while black arrows point to the passage number at which "late passage "was defined in this study. Cells were collected and analyzed at P4 and in late passage.

al., 2007b). Nevertheless, some human BMMSC cultures can bypass senescence and give rise to spontaneously transformed clones (Rubio et al., 2005; Rubio et al., 2008b) with characteristics of poorly differentiated carcinomas (Rubio et al., 2008a). Interestingly, these cells express embryonic antigens and can integrate into blastocysts without forming tumors in chimeric mice, suggesting that some de-differentiation has taken place (Rubio et al., 2008a). Telomerase-immortalized BMMSCs can also display transformation and tumorigenicity (Burns et al., 2005). Moreover, human neuronal stem cells derived from glioma tissue can also transform into tumorigenic cells and undergo genomic instability driven by a high number of DNA double strand breaks and a constitutively overactivated DNA damage response (Shiras et al., 2007). We recently reported that one out of six long-term cultures of adipose stem cells (ASCs) display minor telomeric deletions, primarily in early passage and in a subpopulation that is subsequently and spontaneously eliminated from culture (Meza-Zepeda et al., 2008). Thus, chromosomal aberrations may occur in a fraction BM- and adipose-derived MSC cultures, but their incidence appears to be negligible in long-term human MSC cultures (Bernardo et al., 2007b).

Fetal bovine serum (FBS) remains to date the primary source of growth supplements and low molecular weight bioactive compounds for long-term in vitro expansion of MSCs (Kume et al., 2006). FBS may however have undesirable effects in therapeutic applications due to risks of contamination by pathogens or transmission of xenogeneic proteins (reviewed in Mannello and Tonti, 2007). Yet, there are to date no documented significant effects of FBS in published clinical trials using human MSCs (Sotiropoulou et al., 2006; Berger et al., 2006; Mannello and Tonti, 2007; Le Blanc K. et al., 2008). Nevertheless, alternative sources of growth supplements are being investigated. Replacement of FBS with pooled allogeneic $A B$ serum (Kocaoemer et al., 2007; Kunisaki et al., 2007), thrombin-activated platelet-rich plasma (KocaoemerÄet al., 2007), human platelet lysate (Lange et al., 2007; Schallmoser et al., 2007), or bovine fibroblast growth factor (Battula et al., 2007) supports equal or greater proliferation and/or multilineage differentiation of human BM-, adipose- or amniotic fluid-derived MSCs (Mannello and Tonti, 2007). BMMSCs expanded in medium containing autologous serum (AS) proliferate faster and differentiate less rapidly than cells cultured with FBS (Shahdadfar et al., 2005). Gene expression profiling also shows that BMMSCs in AS display enhanced stability in gene expression, suggesting that they may be expanded more stably in AS than in FBS (Shahdadfar et al., 2005). On the other hand, BMMSCs expanded to late passage in FBS-supplemented medium have shown no signs of genetic instability or transformation in a study involving 10 donors (Bernardo et al., 2007b). There is however to date no side-by-side study on how FBS and AS affect genomic and epigenetic stability of MSCs during extended culture.

Epigenetic processes are heritable modifications of DNA and chromatin that affect gene expression without altering genomic sequence. A primary component of epigenetics is methylation of cytosines in cytosine-phosphate-guanine (CpG) dinucleotides. DNA methylation favors genomic integrity and ensures proper regulation of gene expression. Corruption of DNA methylation in long-term culture of primary cells, including ASCs (Noer et al., 2006; Boquest et al., 2007), are predominantly caused by stochastic $\mathrm{CpG}$ methylation events reflecting errors in the maintenance methylation machinery (Graff et al., 2000; Bird, 2002). DNA methylation is associated with longterm gene silencing (Antequera, 2003), thus methylation of tumor suppressor genes may lead to cellular transformation (Laird, 2005). Similarly, hypermethylation of specific promoters may affect the fate of cultured MSCs.

Using array comparative genomic hybridization (CGH), we examine here to what extent human BMMSCs cultured in FBS or AS are prone to localized DNA gains and losses in a range of passages at which cells may be used clinically. We also analyzed by combined bisulfite restriction analysis (COBRA) 
and bisulfite sequencing the $\mathrm{CpG}$ methylation pattern in the promoter of cancer-related genes in BMMSCs expanded in FBS- or AS-containing medium.

\section{Results}

\section{Expansion of BMMSCs in AS and FBS}

There was variability in the proliferative capacity of BMMSCs between donors, in either FBS or AS, and no serum supported proliferation better than the other (Fig. 1). Consistent with our previous observations (Shahdadfar et al., 2005), MSCs from donor 3 proliferated faster in AS than in FBS (population doubling time in log phase of growth was $62 \mathrm{~h}$ vs. $93 \mathrm{~h}$, respectively). However, for the other two donors population doubling time was shorter in FBS than AS (donor 1: 65 h vs. 82 $\mathrm{h}$; donor 2: $58 \mathrm{~h}$ vs. $70 \mathrm{~h}$ ). Late passage characteristics were marked by increased population doubling time, variation in cell size and shape, and a flattened appearance consistent with features of senescent human fibroblasts (data not shown) (Hayflick, 2003).

\section{CGH analysis of changes in DNA copy number in BMMSCs expanded in AS and FBS}

We investigated at high resolution DNA gains or losses in BMMSCs expanded in AS or FBS to early passage (P4) and late passage (P10-P18 depending on the culture; Fig. 1), by $\mathrm{CGH}$ using 385,000 oligonucleotide arrays. Genomic gains and losses detected on each chromosome in all cultures are summarized in Figure 2A, with whole-genome profiles'of DNA copy numbers shown in Figure 2B (donor 1) and Supplementary Figure 1 (see: http://dx.doi.org/10.1387/ijdb.082663jd; donors 2 and 3). The cultures showed primarily telomeric deletions on a variable number of chromosomes. For donor 1, telomeric deletions on chromosomes 4, 5, 7, 8, 10-13, 21 and $X$ were detected, along with a deletion of chromosome 22, but only in FBS and at P4 (Fig. 2A,B). The deleted regions contained variable numbers of genes (Table 1; listed in Supplementary Table 1) and on the basis of the $\log _{2}$ ratios (Table 1 ) affected only a subpopulation of cells. Notably, none of the deletions were significant in late passage cells (Fig. $2 A-C$ ), suggesting that most cells in the subpopulation harboring these deletions were eliminated from the culture beyond P4. Cells from donor 1 expanded in AS did not show significant DNA copy number alterations at any passage (Fig. 2A-C).

Cells from donor 2 remained stable in early and late passage regardless of serum origin, with only two minor telomeric deletions on 5p15.33 and 12q24.33 in FBS at P15 (Fig. 2A). Each of these deletions encompassed a small number of genes (Table 1; Supplementary Table 1). Cells expanded in AS showed a normal DNA content. In cells from donor 3 , the alterations detected were independent of passage number (Fig. 2A). In FBS, telomeric deletions occurred'at P4 on 5p15.55 and 8p23.3 and abnormalities increased at P12. In contrast in AS, telomeric deletions'were detected on chromosomes 4, 5, 13 and 18 together with a chromosome 22 deletion at P4, all in a subpopulation of cells (Table 1). These however were no longer significant at P18 (Fig. 2A), arguing again for the elimination of the majority of the affected cells in late passage in AS.

These results indicate that BMMSC culture in either FBS or AS may cause donor-dependent occasional aberrations in

TABLE 1

\section{ARRAY CGH ANALYSIS OF BMMSCS EXPANDED TO LATE PASSAGE IN FETAL BOVINE SERUM OR AUTOLOGOUS SERUM}

\begin{tabular}{|c|c|c|c|c|c|c|c|}
\hline Sample & NimbleGen ID & Chromosome & $\begin{array}{l}\text { Position start of gain } \\
\text { or loss }(\mathrm{Kb})\end{array}$ & $\begin{array}{l}\text { Position end of gain } \\
\text { or loss }(\mathbf{K b})\end{array}$ & $\begin{array}{l}\text { Fragment size } \\
(\mathrm{Kb})\end{array}$ & $\log _{2}$ ratio $^{a}$ & No. genes ${ }^{b}$ \\
\hline \multicolumn{8}{|l|}{ Donor 1} \\
\hline \multirow[t]{11}{*}{ FBS, P4 } & 1178902 & $4 p 16.3-16.1$ & 30 & 9810 & 9780 & -0.302 & 136 \\
\hline & & $5 p 15.33$ & 90 & 3930 & 3840 & -0.384 & 36 \\
\hline & & 7p22.3-22.2 & 150 & 3270 & 3120 & -0.392 & 44 \\
\hline & & $8 q 24.23-24.3$ & 139170 & 146421 & 7251 & -0.324 & 122 \\
\hline & & $10 q 26.3$ & 133350 & 135328 & 1978 & -0.458 & 39 \\
\hline & & 11p15.5-15.4 & 210 & 3810 & 3600 & -0.387 & 112 \\
\hline & & $12 q 24.33$ & 129090 & 132264 & 3174 & -0.403 & 42 \\
\hline & & $13 q 34$ & 109110 & 114122 & 5012 & -0.322 & 41 \\
\hline & & $21 \mathrm{q} 22.3$ & 41430 & 46923 & 5493 & -0.428 & 96 \\
\hline & & $22 q 11.21-q 13.33$ & 14670 & 49570 & 34900 & -0.277 & 595 \\
\hline & & Xq28 & 152190 & 153510 & 1320 & -0.486 & 55 \\
\hline \multicolumn{8}{|l|}{ Donor 2} \\
\hline \multirow[t]{2}{*}{ FBS, P15 } & 1207802 & $5 p 15.33$ & & 3810 & 3720 & -0.345 & 36 \\
\hline & & $12 q 24.33$ & 129090 & 131910 & 182820 & -0.338 & 42 \\
\hline \multicolumn{8}{|l|}{ Donor 3} \\
\hline \multirow[t]{2}{*}{ FBS, P4 } & 1193602 & $5 p 15.33$ & 90 & 3810 & 3720 & -0.303 & 36 \\
\hline & & 8p23.3 & 150 & 2190 & 2040 & -0.388 & 16 \\
\hline \multirow[t]{7}{*}{ FBS, P12 } & 1182202 & $2 p 25.3-25.2$ & 30 & 4050 & 4020 & -0.384 & 21 \\
\hline & & $2 q 14.2$ & 120810 & 121710 & 900 & -0.437 & 4 \\
\hline & & $3 q 29$ & 194910 & 199323 & 4413 & -0.254 & 54 \\
\hline & & $4 \mathrm{p} 16.3-16.1$ & 30 & 9750 & 9720 & -0.302 & 136 \\
\hline & & $5 \mathrm{p} 15.33$ & 90 & 2850 & 2760 & -0.441 & 35 \\
\hline & & 8p23.3 & 270 & 2190 & 1920 & -0.526 & 13 \\
\hline & & $8 q 24.23-24.3$ & 139710 & 146241 & 6531 & -0.351 & 122 \\
\hline \multirow{5}{*}{ AS, P4 } & 1183902 & 4p16.3-16.1 & 30 & 9950 & 9920 & -0.325 & 136 \\
\hline & & $5 p 15.33$ & 90 & 2790 & 2700 & -0.428 & 33 \\
\hline & & $13 q 34$ & 109590 & 114122 & 4532 & -0.307 & 40 \\
\hline & & $18 q 23$ & 74370 & 76096 & 1726 & -0.393 & 14 \\
\hline & & $22 q 11.21-q 13.33$ & 14670 & 49570 & 34900 & -0.277 & 595 \\
\hline
\end{tabular}

a $A$ positive $\log _{2}$ value indicates a DNA gain, a negative value indicates a DNA loss.

${ }^{b}$ Genes are listed in Supplementary Table 1. 
Fig. 2. Array comparative genomic hybridization (CGH) profile of bone marrow mesenchymal stem cells (BMMSCs) expanded in autologous serum (AS) or fetal bovine serum (FBS) to $\mathbf{P 4}$ and to late passage. (A) $C G H$ summary, shown as DNA gains (green boxes) and deletions (orange boxes) in indicated chromosome regions. Genomic regions were defined by nucleotide number according to the Ensembl database in Table 1, and the list of genes included in each region is given in Supplementary Table 1 (see: http:/ /dx.doi.org/10.1387/ijdb.082663jd). (B) Whole-genome array CGH analysis of BMMSCs cultured to P4 and P10 (late passage) in FBS- and AS-supplemented medium for donor 1. DNA gains and losses are shown as $\log _{2}$ values relative to DNA from uncultured cells from the same donor (reference diploid DNA), with a window size of $300 \mathrm{~Kb}$. Profiles of each chromosome (numbered) are shown. Data for donors 2 and 3 are shown in Supplementary Figure 1. (C) DNA copy number changes throughout chromosomes 1 (top panels) and 7 (bottom panels) in BMMSCs cultured in FBS (left panels) or AS (right panels) to P4 and P10 (donor 1). Chromosome 1 shows no significant changes in DNA copy number. Chromosome 7 displays a telomeric deletion (orange arrow) in FBS at P4, while the deletion is absent at P10. All cultures show apparent pericentromeric gains on chromosome 7 (green arrows). Normalized $\log _{2}$ ratios (y-axis) using a window size of $60 \mathrm{~Kb}$ are plotted in black and their segmentation drawn in red.

\section{A}

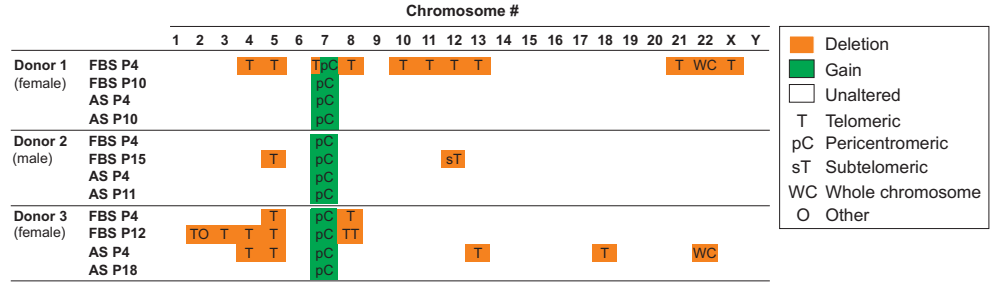

B

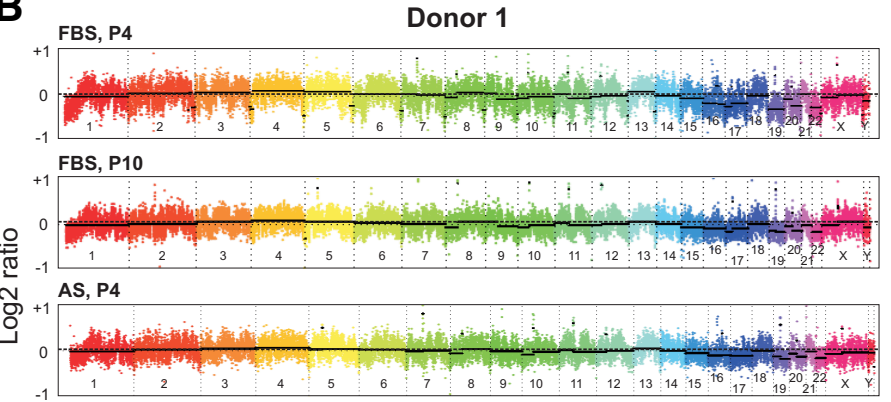
AS, P10

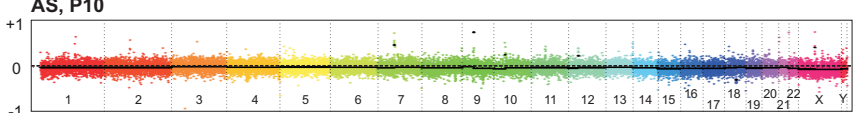

C

Donor 1
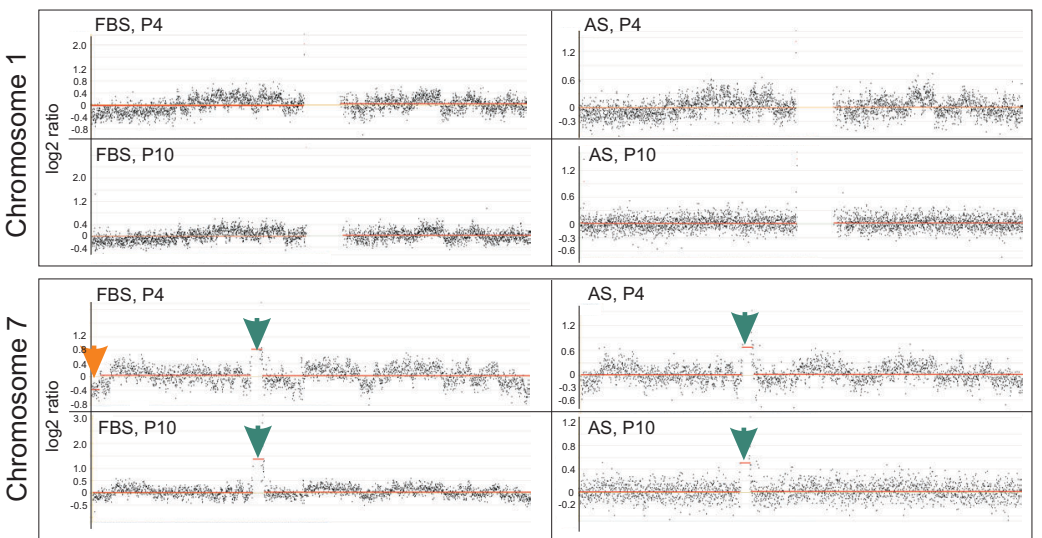

Fig. 3. COBRA analysis of DNA methylation in the promoter of 170 genes in BMMSCs expanded to P4 and late passage in AS or FBS. (A) COBRA methylation profiles of CD14, GNAS, SFN and CCNA1 detected by agarose gel electrophoresis. Arrowheads point to uncut $P C R$ products (umethylated DNA) while brackets delineate PCR products digested by the enzymes (methylated DNA). U, undigested sample; $D$, sample digested with enzymes. (B) Percentage of genes showing unmethylated (green) or methylated (red) DNA patterns under each culture condition; number of genes is indicated in parenthesis. P. late, late passage (pool of P10-P18 cells; see Fig.1).
A

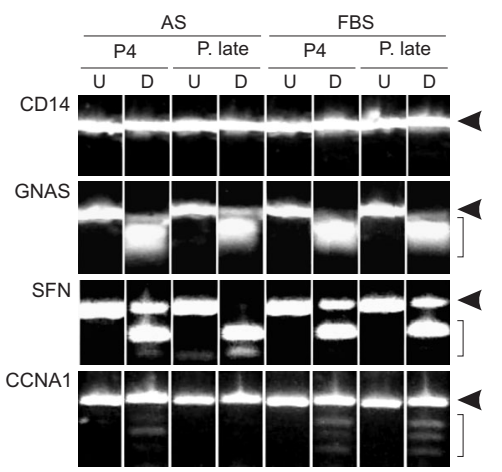

B

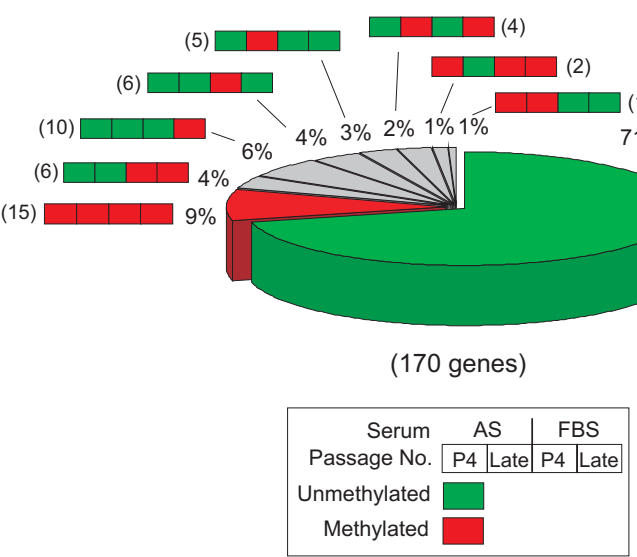


gene copy number primarily in the form of telomeric deletions, in a subpopulation of cells. However, for the three donors, cells in AS generated late passage cultures without significant imbalanced chromosomes rearrangements. In addition, all cultures showed a pericentromeric DNA gain in chromosome 7 (Fig. 2A), consistently at the same location (Fig. 2C, green arrows) and in a segment containing no annotated genes. Similar pericentromeric gains were recently reported in ASCs (MezaZepeda et al., 2008). The possibility remains at present that these alterations represent hybridization artifacts caused by their proximity to areas with satellite repeats or reflect instability of microsatellite repeats in culture.

\section{AS shows a higher propensity than FBS to maintain DNA methylation patterns}

To assess the degree of epigenetic stability of BMMSCs during long-term culture in FBS or AS, we examined the state of DNA methylation in the regulatory region of a panel of 170 cancerrelated genes by COBRA. An NCBI (www.ncbi.nlm.nih.gov) and HUGO (www.genenames.org) database search revealed that these genes encompass oncogenic, tumor suppressor, cell cycle regulation, cell adhesion/migration, DNA metabolism and cell metabolism functions (Supplementary Table 2). To ensure enough material for both COBRA and bisulfite sequencing (see below), and at the same time average out putative between-donor variation in methylation patterns, BMMSC DNA from the three donors was pooled. This was motivated by our earlier observations that ASCs show the same variation in DNA methylation patterns between donors as between cultured or uncultured cells from one donor (Noer et al., 2006; Boquest et al., 2007).

We found that $71 \%$ of the genes examined were unmethylated at P4 and at late passage both in AS and FBS (see e.g., Fig. 3A, $C D 14$ ), while $9 \%$ were methylated in both sera (Fig. 3A, GNAS, SFN, Fig. 3B; Supplementary Fig. 2). Thus, $80 \%$ of the genes maintained their methylation state between $\mathrm{P} 4$ and late passage in both sera. Thirty-four genes (20\%) displayed a different methylation pattern in AS and FBS (Fig. 3A, CCNA1; Fig. 3B; Supplementary Fig. 2). Among these, 22 were stably unmethylated in AS while being stably methylated or changing methylation state in FBS, whereas significantly fewer genes $(6 ; P<0.01$; Fischer's test) were stably unmethylated in FBS while undergoing methylation or being stably methylated in AS. In addition, 4 genes underwent methylation between $\mathrm{P} 4$ and late passage in both sera (Fig. 3B; Supplementary Fig. 2), reflecting for these genes a serum-independent effect of culture on methylation. Therefore, $\geq 90 \%$ of the genes examined maintain their DNA methylation state between $\mathrm{P} 4$ and late passage in either serum. Among these, nearly $90 \%$ display a similar methylation state in both sera, with most genes being unmethylated. There is also a higher propensity of AS than FBS to maintain the unmethylated state in long-term culture, and overall, all functional groups were represented in genes exhibiting specific methylation states.

We used genomic bisulfite sequencing to verify the CpG methylation profiles at the single nucleotide level of 34 randomly chosen genes previously analyzed by COBRA (Supplementary Fig. 3). We found robust consistency between COBRA and sequencing results for genes that were stably unmethylated or stably methylated, as well as for genes with variable methylation patterns (Fig. 4). For a handful of genes, we detected an apparent

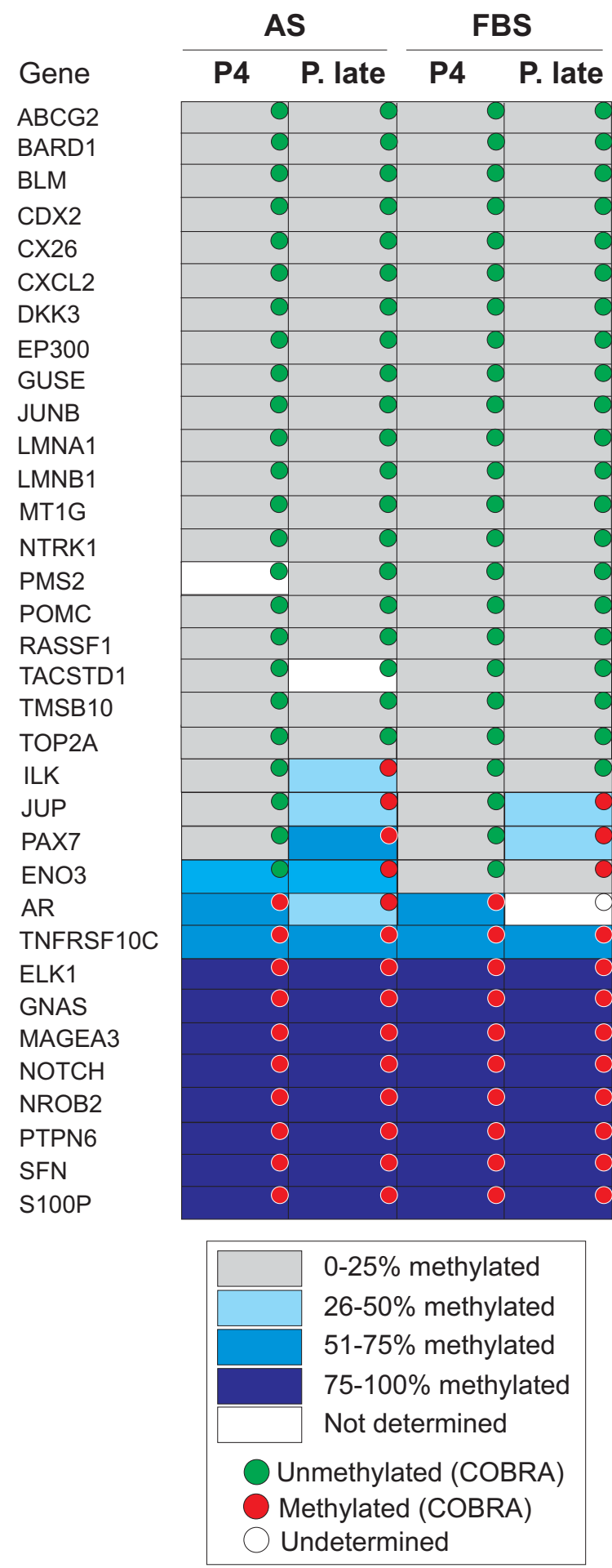

Fig. 4. Bisulfite genomic sequencing analysis of CpG methylation. $C p G$ methylation was determined by direct sequencing of $P C R$ products for 34 genes out of the 170 examined by COBRA in Figure 3. Each window is color-coded to represent the average percentage of methylation calculated from bisulfite sequencing data. $\mathrm{CpG}$ methylation profiles for each locus are shown in Supplementary Figure 3. The red and green dots symbolize the DNA methylation state identified by COBRA. Blank boxes and dot indicate that no data were obtained. P. late, late passage (pool of P10-P18 cells; see Fig.1). 
A

(8)

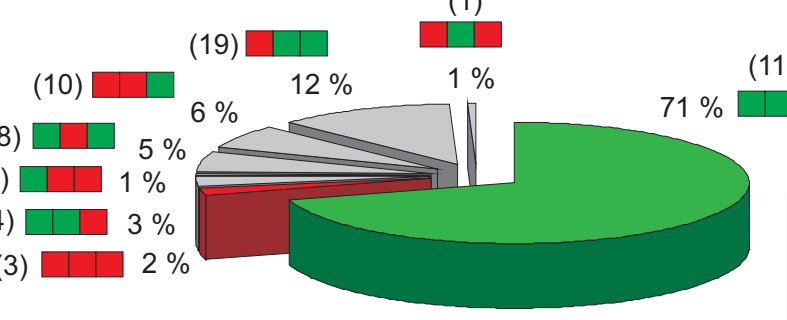

Passage No. \begin{tabular}{|l|l|l|}
\hline$U$ & P5 & P15 \\
\hline
\end{tabular}

Unmethylated Methylated

(156 genes)

B

Unmethylated genes
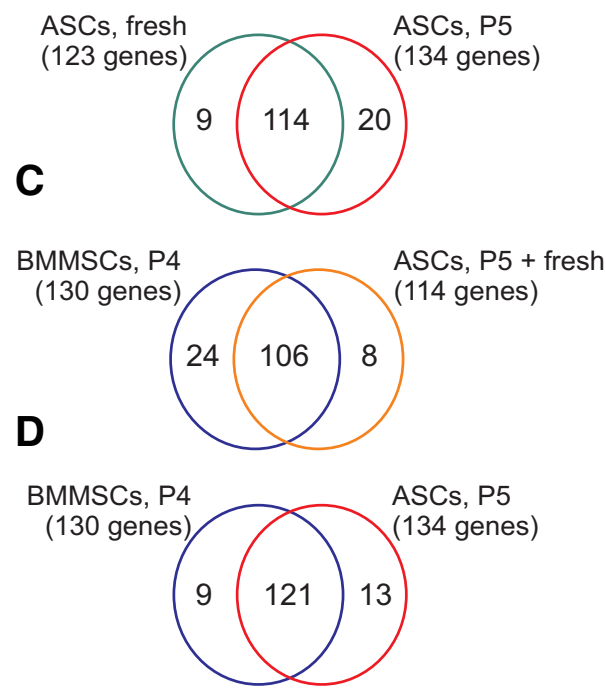

E
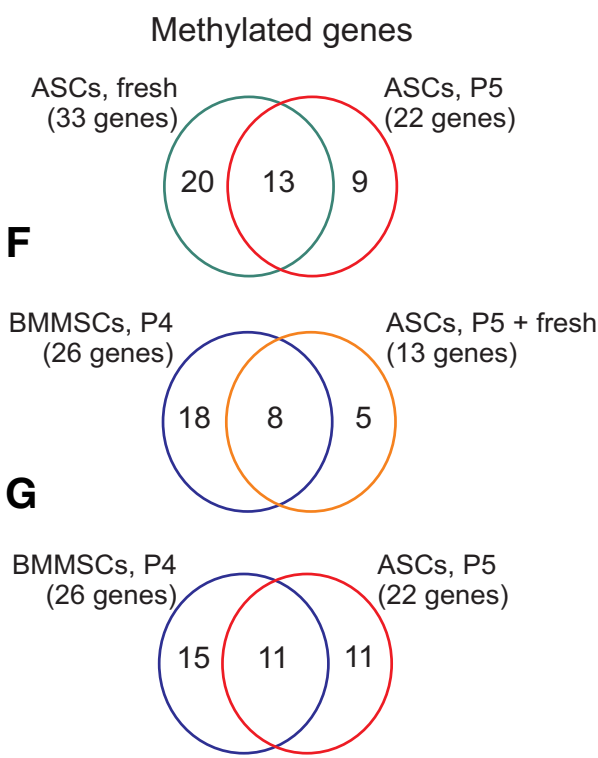

Fig. 5. Relationship between DNA methylation patterns in ASCs and BMMSCs. (A) COBRA analysis of DNA methylation in ASCs that were uncultured (freshly isolated), cultured to P5 and cultured to P15 (late passage) in FBS-supplemented medium. Numbers of genes in each category are indicated in parentheses. (B-G) Venn diagrams of the relationship between methylation states in ASCs (freshly isolated and/or cultured to P5, as indicated) and BMMSCs cultured to P4. Venn diagrams for unmethylated genes (B-D) and methylated genes (E-G) are shown.

discrepancy between COBRA (unmethylated pattern) and bisulfite sequencing (methylated pattern), which was due to the location of these CpGs outside the cutting sites for Bst $U$ and Taq1 enzymes used in the COBRA assay (Supplementary Fig. 3).

\section{Relationship between DNA methylation and DNA copy num- ber}

We next examined whether DNA methylation changes detected correlated with an alteration in DNA copy number. Only 9 $(5 \%)$ genes examined by COBRA were affected by changes in copy number in one or more donors. Among these, four (CDKN1C, CHFR, S100P, BDH1) were affected by deletions in donors 1 (FBS, P4) and 3 (FBS, P12; Supplementary Table 1), but showed stable methylation (Supplementary Fig. 2, genes marked with an asterisk). Five genes included in the COBRA assay localized on chromosome 22, which CGH analysis revealed to be deleted in a proportion of cells in donor 1 (FBS, P4) and 3 (AS, P4) (Fig. 2A). These genes (JUNB, LIM2, GIPC1, STK11, VAV1) were stably unmethylated in both AS and FBS. These observations confirm that deletions detected by $\mathrm{CGH}$ concern a subpopulation of cells and do not affect the methylation level detected by COBRA.

The unmethylated state of DNA in freshly isolated MSCs is preserved more efficiently than the methylated state during culture

To examine how culture perse would affect the DNA methylation state of freshly isolated MSCs, we turned to ASCs which, after purification from the stromal vascular fraction of adipose tissue, can be analyzed in the freshly isolated, uncultured state (Boquest et al., 2005). Isolation of BMMSCs, in contrast, involves-a culture step, and there is currently no published way of determining the methylation state of the putative mesenchymal population of progenitor cells in BM. In addition, although both BMMSCs and ASCs are heterogeneous in nature (Boquest et al., 2005; Kucia etal., 2005), ASCs have a similar immunophenotype and gene expression profile to BMMSCs (Freitas and Dalmau, 2006: Kern et al., 2006), display a similar in vitro differentiation potential (Kern etal., 2006) and similar genome-wide DNA methylation profiles on promoters (A.L. Sørensen and P.C., unpublished data). We have therefore analyzed by COBRA the methylation state of the 170 cancer-related genes examined above, in ASCs that were either freshly isolated, cultured to P5, or cultured to P15 (late passage) in FBS, under the same conditions as BMMSCs. Out of the 170 genes we obtained methylation information on 156 in ASCs (Fig. 5A; Supplementary Fig. 4). Of these, $71 \%$ were unmethylated in freshly isolated ASCs and remained unmethylated throughout culture to $\mathrm{P} 15$. In addition, $2 \%$ of genes methylated in uncultured ASCs remained methylated in culture while $30 \%$ of methylated genes underwent demethylation by P5 (19 genes) or P15 (10 genes). A minor proportion of genes unmethylated in uncultured cells were methylated upon culture (Fig. 5A). Thus, DNA methylation in ASCs behaves overall as in BMMSCs in FBSsupplemented culture, with most genes $(72 \%)$ maintaining their methylation pattern, and the vast majority of which are unmethylated.

We next focused our analysis on methylation states in freshly isolated (uncultured) and early passage ASCs relative to that of early passage BMMSCs. Among the 156 genes examined, 134 were unmethylated at P5 in ASCs; 123 genes were also found to be unmethylated in freshly isolated, uncultured cells, of which 114 
(93\%) remained unmethylated at P5 (Fig. 5B). Thus in ASCs, most genes unmethylated in early passage culture are also found to be unmethylated in freshly isolated cells. Interestingly, among the 114 unmethylated genes, 106 (93\%) were shared with the 130 genes unmethylated in BMMSCs at P4 (Fig. 5C). Of the 134 unmethylated ASC genes at P5, we found 121 (90\%) also unmethylated at BMMSCs at P4 (Fig. 5D). This indicates that most genes unmethylated in early passage culture of BMMSCs are also unmethylated in early passage culture of ASCs, and importantly, nearly all genes unmethylated commonly in BMMSCs and ASCs in early passage culture are unmethylated in freshly isolated ASCs.

There was less consistency among methylated genes. Of the 156 genes with methylation information, 22 were methylated at P5 in ASCs. Thirty-three genes were also methylated in freshly isolated cells, of which $13(39 \%)$ remained methylated at P5 (Fig. $5 \mathrm{E})$. Among these 13 genes, 8 (61\%) were shared with the 26 genes found to be methylated in BMMSCs at P4 (Fig. 5F). Of the 22 genes methylated in ASCs at P5, 11 (50\%) were also found to be methylated in BMMSCs at P4 (Fig. 5G). Therefore, approximately half of the genes found to be methylated in early cultures of both ASCs and BMMSCs are also methylated in freshly isolated ASCs. These results collectively argue that the methylated state of promoters in uncultured ASCs is less likely to be maintained upon culture than the unmethylated state $(P<0.004$; Fisher's exact test).

\section{Discussion}

\section{Genomic stability and DNA methylation patterns in long-term BMMSC culture}

Despite advancements in cell culture techniques, clinical applications of MSCs require the elaboration of better suited culture media with human-derived and/or defined factors (Moore, 2006; Mannello and Tonti, 2007). We have earlier reported that AS supports BMMSC proliferation and mesodermal multilineage differentiation and maintains a more stable gene expression profile than FBS (Shahdadfar et al., 2005). We now show that AS maintains long-term genomic stability of BMMSCs at least as well as FBS and tends to preserve DNA methylation states better than FBS. Thus at present, there is no cellular-based counter-indication for supplementing culture media with AS for expanding human MSCs. Alterations in DNA copy number on several chromosomes can occur during culture in both AS and FBS, however all AS cultures yielded normal gene copy numbers for all donors in late passage. Unlike in our study, no significant chromosomal aberrations were found in a CGH analysis of BMMSCs cultured to P3 and P11-15 with FBS (Bernardo et al., 2007a; Bernardo et al., 2007b). However, the limited scale of the changes in DNA copy numbers detected in our study (as judged by the $\log _{2}$ ratios of DNA copy number relative to normal diploid cells), thresholds for the identification of significantly affected regions, and differences in array platforms and analysis algorithms may account for the apparent discrepancy between these and our studies. The results nonetheless indicate that genomic instability in BMMSC cultures reflects donor variability and/or variability between bovine serum lots.

Among genes displaying changes in promoter DNA methylation in BMMSCs during culture, $90 \%$ were located in genomically stable regions, indicating that methylation changes observed are unrelated to aberrant gene copy number. Additionally, we detected more genes undergoing methylation over time (regardless of serum source), than genes undergoing demethylation. Bisulfite sequencing analysis illustrates that methylation occurs over the entire regions examined (Supplementary Fig. 3), yet a stochastic component cannot be excluded (Noer et al., 2007). We have notably identified four genes showing methylation upon prolonged culture in either FBS or AS, suggesting that these may be programmedÄto be transcriptionally repressed (Jones and Takai, 2001). Two of these genes are involved in cell adhesion, genomic stability and oncogenesis. CD248/TEM1 (endosialin) encodes an embryonic fibroblast antigen also expressed in cancers (Rettig et al., 1992) and involved in cell adhesion, migration and tumor invasion (Tomkowicz et al., 2007). CD248/TEM1 methylation in long-term culture may permanently inactivate the gene, eliminating the possibility of endosialin-dependent migration of BMMSCs. Furthermore, JUP encodes junction plakoglobin ( $\gamma$-catenin), a desmosome component implicated in cancer progression (Barker and Clevers, 2000; Chidgey and Dawson, 2007). $\gamma$-catenin overexpression also increases $M Y C$ expression, which leads to genomic instability (Pan et al., 2007). Thus as for CD248/TEM1, JUP promoter methylation may indirectly contribute to inhibition of cell migration and maintenance of genomic stability. Methylation driven changes in cancer cell invasive properties as a function of microenvironment have been shown for the E-cadherin promoter in breast cancer cells (Graff et al., 2000).

\section{Dynamics of DNA methylation in BMMSCs expanded in AS and FBS}

DNA methylation reflects the establishment of a long-term transcriptional program, thus in a context where the genes examined in our study were found to be not significantly up- or downregulated in long-term culture (Shahdadfar et al., 2005), we did not expect to see dramatic methylation changes. Indeed, despite the methylation change reported for 4 genes (see above), the majority of the genes examined in this study showed unaltered methylation between $\mathrm{P} 4$ and late passage (P10-P18) both in AS and FBS. Thus, both sera overall preserve $\mathrm{CpG}$ methylation patterns, and only focused methylation changes occur. Interestingly however, among genes with a different methylation state in AS and FBS, we identified significantly more genes that are stably unmethylated in AS than in FBS. This suggests that AS has a greater propensity than FBS to maintain an unmethylated state upon long-term culture. We previously found that BMMSCs cultured in FBS differentiate more readily than in AS (Shahdadfar et al., 2005), suggesting the initiation of a differentiation program in FBS. A possibility is that components in FBS, more so than AS, elicit a non-random DNA methylation drift during MSC culture, on top of seemingly stochastic alterations (Noer etal., 2007), such as that suggested to take place in embryonic stem cell cultures (Maitra et al., 2005; Bibikova et al., 2006; Allegrucci et al., 2007). These methylation changes may pre-program BMMSCs toward mesodermal differentiation by, notably, affecting expression of cell cycle inhibitors (Shahdadfar et al., 2005). It is conceivable, therefore, that AS contributes to perpetuating a less differentiated state than FBS by maintaining methylation patterns.

In light of these observations, what is the DNA methylation pattern of MSCs in vivo? Current protocols for isolation of BMMSCs 
require a culture step, thus there is no data on DNA methylation profiles in the putative MSC subpopulation in bone marrow. To get one step closer to resolving this issue, we analyzed DNA methylation in freshly isolated and in cultured ASCs, and compared methylation states with that of BMMSCs, This approach was motivated by reports that ASCs resemble (but are not identical to) BMMSCs at the morphological, transcriptional and surface marker expression levels (Boquest et al., 2005; Fraser et al., 2006), as well as at the genome-wide DNA methylation level (A.L. Sørensen and P.C., unpublished data). We conclude from these observations that $\sim 80 \%$ of genes examined in ASCs retain their methylation state between isolation and culture, and most of these genes are unmethylated in the cultured state. Moreover, the vast majority of genes that are unmethylated commonly in BMMSCs and in ASCs in early passage culture are also unmethylated in freshly isolated ASCs. Thus, we tentatively speculate that most genes unmethylated in BMMSCs cultured to P4, regardless of serum origin, are also unmethylated in vivo.

We demonstrate here localized genomic and DNA methylation instabilities during in vitro expansion of human BMMSCs in a range of passages where cells may be used clinically. Although other studies report the absence of genomic alterations in BMMSCs cultured in FBS (Bernardo et al., 2007a; Bernardo et al., 2007b), the risk of alterations in gene copy number and spontaneous oncogenic transformation exists for human MSCs (Meza-Zepeda et al., 2008; Rubio et al., 2008a), irrespective of serum source (this study). Epigenetic drifting may also occur at the DNA methylation level, although this seems to affect a limited number of genes. Thus, in a clinical setting, caution should be exerted prior to transplanting MSCs by applying appropriate tests to ensure integrity of the genome and epigenome.

\section{Materials and Methods}

\section{Autologous serum}

From each BM donor, $\sim 500 \mathrm{ml}$ of whole blood was allowed to clot for $4 \mathrm{~h}$ at $4-8^{\circ} \mathrm{C}$ and centrifuged at $1,800 \mathrm{~g}$ at $4^{\circ} \mathrm{C}$ for $15 \mathrm{~min}$. Serum was collected, filtered through a $0.2 \mu \mathrm{m}$ membrane and aliquots (AS) were stored at $-20^{\circ} \mathrm{C}$ (Shahdadfar et al., 2005).

\section{Isolation and culture of BMMSCs}

MSCs were isolated from bone marrow from three healthy donors (one male, two females) as described (Shahdadfar et al., 2005). Cells were plated overnight in DMEM/F12 containing $20 \%$ AS or FBS, and antibiotics. On day 1 , the medium was replaced with a fresh portion containing $20 \%$ AS or FBS. Cells were subcultured by trypsinization at $50 \%$ confluency and seeded at 5,000 cells $/ \mathrm{cm}^{2}$. After the first passage, amphotericin B was removed and $10 \%$ of either AS or FBS was used throughout the culture. Viable cells were counted at each passage and medium replaced every 2-3 days. Cells were harvested at passage 4 (P4) and at late passage (P10-P18 depending on the culture; see Fig. 1) and frozen as dry pellets or in DMSO as viable cells.

\section{Isolation and culture of ASCs}

ASCs were purified from the stromal vascular fraction of human liposuction material from three donors as described previously (Boquest et al., 2005). Briefly, stromal cells were isolated by collagenase and DNase digestion, sedimentation and straining. CD $45^{+}$and $\mathrm{CD} 31^{+}$cells were removed from the stromal cells by double negative selection, resulting in CD45-CD31- cells (ASCs) (Boquest et al., 2006). ASCs were plated overnight in DMEM/F12 with $50 \%$ FBS and further cultured in
DMEM/F12/10\% FBS. Cells were passaged $1: 3$ by trypsinization. Cultures from three donors were pooled to eliminate any donor variation. Purified uncultured ASCs were directly processed for DNA isolation and COBRA.

\section{DNA isolation and amplification}

For array CGH, DNA was purified by double phenol-chloroformisoamylalcohol extraction and one chloroform-isoamylalcohol extraction after cell lysis in $10 \mathrm{mM}$ Tris- $\mathrm{HCl}, \mathrm{pH} 8.0,100 \mathrm{mM}$ EDTA and $0.5 \%$ SDS, and digestion with $0.1 \mathrm{mg} / \mathrm{ml}$ Proteinase $\mathrm{K}$ overnight. DNA was diluted to $250 \mathrm{ng} / \mu \mathrm{l}$ in nuclease-free $\mathrm{H}_{2} \mathrm{O}$. DNA concentration was measured by Picogreen fluorometry (Invitrogen). DNA was amplified using the Qiagen REPLI-g Mini kit (www.qiagen.com), cleaned up using the QIAmp DNA micro kit (Qiagen) and concentration determined with Picogreen. For bisulfite conversion, DNA was purified as above.

\section{Combined bisulfite restriction analysis}

COBRA of DNA methylation relies on the existence of one or more restriction sites for an enzyme in the amplicon of interest, which after bisulfite conversion will still contain cytosine residues indicating methylation of the region prior to bisulfite treatment (COBRA however excludes assessment of $\mathrm{CpG}$ outside such restriction sites). COBRA was performed (Xiong and Laird, 1997) on a panel of 170 cancer-related genes (Human Genetic Signatures; HGS; www.geneticsignatures.com). Genomic DNA was isolated from BMMSC cultures, bisulfite-converted using the MethylEasy ${ }^{\mathrm{TM}} \mathrm{Xceed}$ (HGS) and fully nested PCRs were performed on the converted DNA using commercially available primers (HGS). PCR conditions were for each gene $95^{\circ} \mathrm{C}$ for $3 \mathrm{~min}$ and 30 cycles of $95^{\circ} \mathrm{C} 1 \mathrm{~min}$, $50^{\circ} \mathrm{C} 2 \mathrm{~min}$ and $72^{\circ} \mathrm{C} 2 \mathrm{~min}$, followed by $10 \mathrm{~min}$ at $72^{\circ} \mathrm{C}$. The same PCR product was used for COBRA and direct sequencing. Products were double digested with BstU (recognition sequence CGCG [TGTG after conversion if $\mathrm{Cs}$ are not methylated]) and Taq1 (TCGA [TTGA after conversion if $\mathrm{Cs}$ are not methylated]) at $60^{\circ} \mathrm{C}$ for $1 \mathrm{~h}$. Amplicons were screened to ensure they contained at least one and in most cases multiple recognition sites for either enzyme. Undigested control PCR products were resolved next to digested products in $2 \%$ agarose gels. Products from methylated DNA templates were digested by the enzymes while those from unmethylated DNA were not.

\section{Bisulfite genomic sequencing}

PCR products generated for COBRA were directly sequenced (SUPAMAC; www.supamac.com) and sequences analyzed with the ABI Sequencing Analysis Software v5.2 using the 3-base genome option to determine relative peaks heights for adenine (reflecting a converted unmethylated cytosine) and guanine (reflecting a non-converted methylated cytosine) (Clark et al., 2006). Extent of methylation for each CpG is shown as a color- and number-coded box in the region examined.

\section{Comparative genomic hybridization}

$\mathrm{CGH}$ was performed on BMMSC cultures as described (Meza-Zepeda et al., 2008). Samples were hybridized onto NimbleGen high-density oligonucleotide microarrays containing 385,000 probes spanning nonrepetitive genic and intergenic regions of the human genome at a median spacing of $~ 6,000$ bp (HG18_WG_CGH; www.nimblegen.com). DNA from peripheral blood lymphocytes from the same BMMSC donors was used as reference diploid sample. Test and reference samples were cohybridized onto the arrays and scanned (NimbleGen). After linking signal intensity to genome coordinates, signals were normalized using qspline normalization (Workman et al., 2002). After normalization, data were prepared for segmentation using an averaging step, with probes within a defined base-pair window size averaged using a Tukey's biweight mean (Lu, 2004). Windows of 60, 120 and $300 \mathrm{~kb}$ were used. Data segmentation was performed using a binary segmentation algorithm (Olshen et al., 2004), which breaks DNA segments into sub-segments by determining the $t$ statistics of the means. We have used 1,000 permutations and a $P$ - 
value of 0.01 to call breakpoints. DNA copy number changes were scored as aberrant when they contained a segmentation $\log _{2}$ value of more than 0.25 (gains) or less than -0.25 (losses), segments contained at least 10 consecutive oligonucleotides using raw normalized data, and aberrations were seen in at least 2 segmentation windows.

\section{Acknowledgments \\ This work was supported by the Research Council of Norway (FUGE, YFF, STORFORSK and STAMCELLE programs) and the Norwegian Cancer Society.}

\section{References}

ALLEGRUCCI, C., WU, Y.Z., THURSTON, A., DENNING, C.N., PRIDDLE, H., MUMMERY, C.L., WARD-VAN, O.D., ANDREWS, P.W., STOJKOVIC, M., SMITH, N., PARKIN, T., JONES, M.E., WARREN, G., YU, L., BRENA, R.M., PLASS, C. and YOUNG, L.E. (2007). Restriction landmark genome scanning identifies culture-induced DNA methylation instability in the human embryonic stem cell epigenome. Hum. Mol. Genet. 16: 1253-1268.

ANTEQUERA, F. (2003). Structure, function and evolution of CpG island promoters. Cell Mol. Life Sci. 60: 1647-1658.

BARKER, N. and CLEVERS, H. (2000). Catenins, Wnt signaling and cancer. BioEssays 22: 961-965.

BATTULA, V.L., BAREISS, P.M., TREML, S., CONRAD, S., ALBERT, I., HOJAK, S., ABELE, H., SCHEWE, B., JUST, L., SKUTELLA, T. and BUHRING, H.J. (2007). Human placenta and bone marrow derived MSC cultured in serum-free, b-FGF-containing medium express cell surface frizzled-9 and SSEA-4 and give rise to multilineage differentiation. Differentiation 75: 279-291.

BERGER, M.G., VEYRAT-MASSON, R., RAPATEL, C., DESCAMPS, S. CHASSAGNE, J. and BOIRET-DUPRE, N. (2006). Cell culture medium composition and translational adult bone marrow-derived stem cell research. Stem Cells 24: 2888-2890.

BERNARDO, M.E., AVANZINI, M.A., PEROTTI, C., COMETA, A.M., MORETTA, A., LENTA, E., DEL, F.C., NOVARA, F., DE, S.A., AMENDOLA, G., ZUFFARDI, O., MACCARIO, R. and LOCATELLI, F. (2007a). Optimization of in vitro expansion of human multipotent mesenchymal stromal cells for cell-therapy approaches: further insights in the search for a fetal calf serum substitute. J. Cell Physiol. 211: 121-130.

BERNARDO, M.E., ZAFFARONI, N., NOVARA, F., COMETA, A.M., AVANZINI, M.A., MORETTA, A., MONTAGNA, D., MACCARIO, R., VILLA, R., DAIDONE, M.G., ZUFFARDI, O. and LOCATELLI, F. (2007b). Human bone marrow derived mesenchymal stem cells do not undergo transformation after long-term in vitro culture and do not exhibit telomere maintenance mechanisms. Cancer Res. 67: 9142-9149.

BIBIKOVA, M., CHUDIN, E., WU, B., ZHOU, L., GARCIA, E.W., LIU, Y., SHIN, S., PLAIA, T.W., AUERBACH, J.M., ARKING, D.E., GONZALEZ, R., CROOK, J., DAVIDSON, B., SCHULZ, T.C., ROBINS, A., KHANNA, A., SARTIPY, P., HYLLNER, J., VANGURI, P., SAVANT-BHONSALE, S., SMITH, A.K., CHAKRAVARTI, A., MAITRA, A., RAO, M., BARKER, D.L., LORING, J.F. and FAN, J.B. (2006). Human embryonic stem cells have a unique epigenetic signature. Genome Res. 16: 1075-1083.

BIRD, A. (2002). DNA methylation patterns and epigenetic memory. Genes Dev. 16: 6-21.

BOQUEST, A.C., NOER, A., SORENSEN, A.L., VEKTERUD, K. and COLLAS, P. (2007). CpG methylation profiles of endothelial cell-specific gene promoter regions in adipose tissue stem cells suggest limited differentiation potential toward the endothelial cell lineage. Stem Cel/s 25: 852-861.

BOQUEST, A.C., SHAHDADFAR, A., BRINCHMANN, J.E. and COLLAS, P. (2006). Isolation of stromal stem cells from human adipose tissue. Methods Mol. Biol. 325: 35-46

BOQUEST, A.C., SHAHDADFAR, A., FRONSDAL, K., SIGURJONSSON, O., TUNHEIM, S.H., COLLAS, P. and BRINCHMANN, J.E. (2005). Isolation and transcription profiling of purified uncultured human stromal stem cells: alteration of gene expression after in vitro cell culture. Mol. Biol. Cell. 16: 1131-1141.

BROOKE, G., COOK, M., BLAIR, C., HAN, R., HEAZLEWOOD, C., JONES, B., KAMBOURIS, M., KOLLAR, K., MCTAGGART, S., PELEKANOS, R., RICE, A.,
ROSSETTI, T. and ATKINSON, K. (2007). Therapeutic applications of mesenchymal stromal cells. Semin. Cell Dev. Biol. 18: 846-858.

BURNS, J.S., ABDALLAH, B.M., GULDBERG, P., RYGAARD, J., SCHRODER, H.D. and KASSEM, M. (2005). Tumorigenic heterogeneity in cancer stem cells evolved from long-term cultures of telomerase-immortalized human mesenchymal stem cells. Cancer Res. 65: 3126-3135.

CHIDGEY, M. and DAWSON, C. (2007). Desmosomes: a role in cancer? Br. J. Cancer 96: 1783-1787.

CLARK, S.J., STATHAM, A., STIRZAKER, C., MOLLOY, P.L. and FROMMER, M. (2006). DNA methylation: bisulphite modification and analysis. Nat. Protoc. 1: 2353-2364.

FRASER, J.K., WULUR, I., ALFONSO, Z. and HEDRICK, M.H. (2006). Fat tissue: an underappreciated source of stem cells for biotechnology. Trends Biotechnol. 24: 150-154.

FREITAS, C.S. and DALMAU, S.R. (2006). Multiple sources of non-embryonic multipotent stem cells: processed lipoaspirates and dermis as promising alternatives to bone-marrow-derived cell therapies. Cell Tissue Res. 325: 403-411.

GRAFF, J.R., GABRIELSON, E., FUJII, H., BAYLIN, S.B. and HERMAN, J.G. (2000). Methylation patterns of the E-cadherin $5^{\prime} \mathrm{CpG}$ island are unstable and reflect the dynamic, heterogeneous loss of E-cadherin expression during metastatic progression. J. Biol. Chem. 275: 2727-2732.

HAYFLICK, L. (2003). Living forever and dying in the attempt. Exp. Gerontol. 38 : 1231-1241.

JIANG, Y., VAESSEN, B., LENVIK, T., BLACKSTAD, M., REYES, M. and VERFAILLIE, C.M. (2002). Multipotent progenitor cells can be isolated from postnatal murine bone marrow, muscle, and brain. Exp. Hematol. 30: 896-904.

JONES, P.A. and TAKAI, D. (2001). The role of DNA methylation in mammalian epigenetics. Science 293: 1068-1070.

KATZ, A.J., THOLPADY, A., THOLPADY, S.S., SHANG, H. and OGLE, R.C. (2005). Cell surface and transcriptional characterization of human adiposederived adherent stromal (hADAS) cells. Stem Cells 23: 412-423.

KERN, S., EICHLER, H., STOEVE, J., KLUTER, H. and BIEBACK, K. (2006) Comparative analysis of mesenchymal stem cells from bone marrow, umbilical cord blood or adipose tissue. Stem Cells 24: 1294-1301.

KOCAOEMER, A., KERN, S., KLUTER, H. and BIEBACK, K. (2007). Human AB serum and thrombin-activated platelet-rich plasma are suitable alternatives to fetal calf serum for the expansion of mesenchymal stem cells from adipose tissue. Stem Cells 25: 1270-1278.

KUCIA, M., RECA, R., JALA, V.R., DAWN, B., RATAJCZAK, J. and RATAJCZAK, M.Z. (2005). Bone marrow as a home of heterogenous populations of nonhematopoietic stem cells. Leukemia 19: 1118-1127.

KUME, T., TAGUCHI, R., KATSUKI, H., AKAO, M., SUGIMOTO, H., KANEKO, S. and AKAIKE, A. (2006). Serofendic acid, a neuroprotective substance derived from fetal calf serum, inhibits mitochondrial membrane depolarization and caspase-3 activation. Eur. J. Pharmacol. 542: 69-76.

KUNISAKI, S.M., ARMANT, M., KAO, G.S., STEVENSON, K., KIM, H. and FAUZA, D.O. (2007). Tissue engineering from human mesenchymal amniocytes: a prelude to clinical trials. J. Pediatr. Surg. 42: 974-979.

LAIRD, P.W. (2005). Cancer epigenetics. Hum. Mol. Genet. 14: R65-R76.

LANGE, C., CAKIROGLU, F., SPIESS, A.N., CAPPALLO-OBERMANN, H. DIERLAMM, J. and ZANDER, A.R. (2007). Accelerated and safe expansion of human mesenchymal stromal cells in animal serum-free medium for transplantation and regenerative medicine. J. Cell Physiol. 213: 18-26.

LE BLANC K., FRASSONI, F., BALL, L., LOCATELLI, F., ROELOFS, H., LEWIS, I., LANINO, E., SUNDBERG, B., BERNARDO, M.E., REMBERGER, M., DINI, G., EGELER, R.M., BACIGALUPO, A., FIBBE, W. and RINGDEN, O. (2008). Mesenchymal stem cells for treatment of steroid-resistant, severe, acute graftversus-host disease: a phase II study. Lancet 371: 1579-1586.

LE BLANC K. and RINGDEN, O. (2007). Immunomodulation by mesenchymal stem cells and clinical experience. J. Intern. Med. 262: 509-525.

LU, C. (2004). Improving the scaling normalization for high-density oligonucleotide GeneChip expression microarrays. BMC. Bioinformatics 5: 103-107.

MAITRA, A., ARKING, D.E., SHIVAPURKAR, N., IKEDA, M., STASTNY, V., KASSAUEI, K., SUI, G., CUTLER, D.J., LIU, Y., BRIMBLE, S.N., NOAKSSON, K., HYLLNER, J., SCHULZ, T.C., ZENG, X., FREED, W.J., CROOK, J., 
ABRAHAM, S., COLMAN, A., SARTIPY, P., MATSUI, S., CARPENTER, M., GAZDAR, A.F., RAO, M. and CHAKRAVARTI, A. (2005). Genomic alterations in cultured human embryonic stem cells. Nat. Genet. 37: 1099-1103.

MANNELLO, F. and TONTI, G.A. (2007). Concise review: no breakthroughs for human mesenchymal and embryonic stem cell culture: conditioned medium, feeder layer, or feeder-free; medium with fetal calf serum, human serum, or enriched plasma; serum-free, serum replacement nonconditioned medium, or ad hoc formula? All that glitters is not gold! Stem Cells 25: 1603-1609.

MEZA-ZEPEDA, L.A., NOER, A., DAHL, J.A., MICCI, F., MYKLEBOST, O. and COLLAS, P. (2008). High-resolution analysis of genetic stability of human adipose tissue stem cells cultured to senescence. J. Cell. Mol. Med. 12: 553563.

MIURA, Y., GAO, Z., MIURA, M., SEO, B.M., SONOYAMA, W., CHEN, W., GRONTHOS, S., ZHANG, L. and SHI, S. (2006). Mesenchymal stem cellorganized bone marrow elements: an alternative hematopoietic progenitor resource. Stem Cells 24: 2428-2436.

MOORE, H. (2006). The medium is the message. Nat. Biotechnol. 24: 160-161.

NOER, A., BOQUEST, A.C. and COLLAS, P. (2007). Dynamics of adipogenic promoter DNA methylation during clonal culture of human adipose stem cells to senescence. BMC. Cell Biol. 8: 18-29.

NOER, A., SøRENSEN, A.L., BOQUEST, A.C. and COLLAS, P. (2006). Stable $\mathrm{CpG}$ hypomethylation of adipogenic promoters in freshly isolated, cultured and differentiated mesenchymal stem cells from adipose tissue. Mol. Biol. Cel/17: 3543-3556.

OLSHEN, A.B., VENKATRAMAN, E.S., LUCITO, R. and WIGLER, M. (2004). Circular binary segmentation for the analysis of array-based DNA copy number data. Biostatistics 5: 557-572.

PAN, H., GAO, F., PAPAGEORGIS, P., ABDOLMALEKY, H.M., FALLER, D.V. and THIAGALINGAM, S. (2007). Aberrant Activation of gamma-Catenin Promotes Genomic Instability and Oncogenic Effects during Tumor Progression. Cancer Biol. Ther. 6: 1638-1643

PITTENGER, M.F., MACKAY, A.M., BECK, S.C., JAISWAL, R.K., DOUGLAS, R., MOSCA, J.D., MOORMAN, M.A., SIMONETTI, D.W., CRAIG, S. and MARSHAK, D.R. (1999). Multilineage potential of adult human mesenchymal stem cells. Science 284: 143-147.

RETTIG, W.J., GARIN-CHESA, P., HEALEY, J.H., SU, S.L., JAFFE, E.A. and OLD, L.J. (1992). Identification of endosialin, a cell surface glycoprotein of vascular endothelial cells in human cancer. Proc. Natl. Acad. Sci USA 89: 10832-10836.

RUBIO, D., GARCIA, S., DE LA, C.T., PAZ, M.F., LLOYD, A.C., BERNAD, A. and GARCIA-CASTRO, J. (2008a). Human mesenchymal stem cell transformation is associated with a mesenchymal-epithelial transition. Exp. Cel/Res. 314:691698.

RUBIO, D., GARCIA, S., PAZ, M.F., DE LA, C.T., LOPEZ-FERNANDEZ, L.A., LLOYD, A.C., GARCIA-CASTRO, J. and BERNAD, A. (2008b). Molecular characterization of spontaneous mesenchymal stem cell transformation. PLOS. ONE. 3: e1398.

RUBIO, D., GARCIA-CASTRO, J., MARTIN, M.C., DE LA, F.R., CIGUDOSA, J.C., LLOYD, A.C. and BERNAD, A. (2005). Spontaneous human adult stem cell transformation. Cancer Res. 65: 3035-3039.

SCHALLMOSER, K., BARTMANN, C., ROHDE, E., REINISCH, A., KASHOFER, K., STADELMEYER, E., DREXLER, C., LANZER, G., LINKESCH, W. and STRUNK, D. (2007). Human platelet lysate can replace fetal bovine serum for clinical-scale expansion of functional mesenchymal stromal cells. Transfusion 47: 1436-1446.

SHAHDADFAR, A., FRONSDAL, K., HAUG, T., REINHOLT, F.P. and BRINCHMANN, J.E. (2005). In vitro expansion of human mesenchymal stem cells: choice of serum is a determinant of cell proliferation, differentiation, gene expression, and transcriptome stability. Stem Cel/s 23: 1357-1366.

SHIRAS, A., CHETTIAR, S.T., SHEPAL, V., RAJENDRAN, G., PRASAD, G.R. and SHASTRY, P. (2007). Spontaneous transformation of human adult nontumorigenic stem cells to cancer stem cells is driven by genomic instability in a human model of glioblastoma. Stem Cel/s 25: 1478-1489.

SOTIROPOULOU, P.A., PEREZ, S.A., SALAGIANNI, M., BAXEVANIS, C.N. and PAPAMICHAIL, M. (2006). Cell culture medium composition and translational adult bone marrow-derived stem cell research. Stem Cells 24: 1409-1410.

TOLAR, J., NAUTA, A.J., OSBORN, M.J., PANOSKALTSIS, M.A., MCELMURRY, R.T., BELL, S., XIA, L., ZHOU, N., RIDDLE, M., SCHROEDER, T.M., WESTENDORF, J.J., MCIVOR, R.S., HOGENDOORN, P.C., SZUHAI, K., OSETH, L., HIRSCH, B., YANT, S.R., KAY, M.A., PEISTER, A., PROCKOP, D.J., FIBBE, W.E. and BLAZAR, B.R. (2007). Sarcoma derived from cultured mesenchymal stem cells. Stem Cells 25: 371-379.

TOMKOWICZ, B., RYBINSKI, K., FOLEY, B., EBEL, W., KLINE, B., ROUTHIER, E. SASS, P., NICOLAIDES, N.C., GRASSO, L. and ZHOU, Y. (2007). Interaction of endosialin/TEM1 with extracellular matrix proteins mediates cell adhesion and migration. Proc. Natl. Acad. Sci USA 104: 17965-17970.

WORKMAN, C., JENSEN, L.J., JARMER, H., BERKA, R., GAUTIER, L., NIELSER H.B., SAXILD, H.H., NIELSEN, C., BRUNAK, S. and KNUDSEN, S. (2002). A new non-linear normalization method for reducing variability in DNA microarray experiments. Genome Biol. 3: 48-55.

XIONG, Z. and LAIRD, P.W. (1997). COBRA: a sensitive and quantitative DNA methylation assay. Nucleic Acids Res. 25: 2532-2534.

ZHANG, Z.X., GUAN, L.X., ZHANG, K., WANG, S., CAO, P.C., WANG, Y.H., WANG, Z. and DAI, L.J. (2007). Cytogenetic analysis of human bone marrowderived mesenchymal stem cells passaged in vitro. Cell Biol. Int. 31: 645-648.

ZUK, P.A., ZHU, M., MIZUNO, H., HUANG, J., FUTRELL, J.W., KATZ, A.J., BENHAIM, P., LORENZ, H.P. and HEDRICK, M.H. (2001). Multilineage cells from human adipose tissue: implications for cell-based therapies. Tissue Eng. 7: 211-228. 


\section{Further Related Reading, published previously in the Int. J. Dev. Biol.}

See our recent Special Issue Fertilization, in honor of David L. Garbers and edited by Paul M. Wassarman and Victor D. Vacquier at: http://www.ijdb.ehu.es/web/contents.php?vol=52\&issue=5-6

See our recent Special Issue Ear Development edited by Fernando Giraldez and Bernd Fritzsch at: http://www.ijdb.ehu.es/web/contents.php?vol=51\&issue=6-7

Acquisition of cell polarity during cell cycle and oral replacement in Tetrahymena Janina Kaczanowska, Szymon Kaczanowski, Mauryla Kiersnowska, Hanna Fabczak, Karolina Tulodziecka and Andrzej Kaczanowski Int. J. Dev. Biol. (2008) 52: 249-258

Loss of Sox9 function results in defective chondrocyte differentiation of mouse embryonic stem cells in vitro Gunnar Hargus, Ralf Kist, Jan Kramer, Daniela Gerstel, Angela Neitz, Gerd Scherer and Jürgen Rohwedel Int. J. Dev. Biol. (2008) 52: 323-332

Embryonic development of the proepicardium and coronary vessels Anna Ratajska, Elzbieta Czarnowska and Bogdan Ciszek Int. J. Dev. Biol. (2008) 52: 229-236

Hypomethylation of paternal DNA in the late mouse zygote is not essential for development Zbigniew Polanski, Nami Motosugi, Chizuko Tsurumi, Takashi Hiiragi and Steffen Hoffmann Int. J. Dev. Biol. (2008) 52: 295-298

DNA methylation state is preserved in the sperm-derived pronucleus of the pig zygote Young-Sun Jeong, Seungeun Yeo, Jung-Sun Park, Deog-Bon Koo, Won-Kyung Chang, Kyung-Kwang Lee and Yong-Kook Kang Int. J. Dev. Biol. (2007) 51: 707-714

Human conjunctival epithelial precursor cells and their progeny in 3D organotypic culture Alfredo Rosellini, Sandra Papini, Claudio Giannarini, Marco Nardi and Roberto P. Revoltella Int. J. Dev. Biol. (2007) 51: 739-743

An efficient method for isolation of murine bone marrow mesenchymal stem cells Samad Nadri, Masoud Soleimani, Reza H. HosSeni, Mohammad Massumi, Amir Atashi and Reza Izadpanah Int. J. Dev. Biol. (2007) 51: 723-729

Fate of cranial neural crest cells during craniofacial development in endothelin-A receptor-deficient mice Makoto Abe, Louis-Bruno Ruest and David E. Clouthier Int. J. Dev. Biol. (2007) 51: 97-105

Enhanced development of porcine embryos cloned from bone marrow mesenchymal stem cells Hai-Feng Jin, B. Mohana Kumar, Jung-Gon Kim, Hye-Jin Song, Yeon-Ji Jeong, SeongKeun Cho, Sivasankaran Balasubramanian, Sang-Yong Choe and Gyu-Jin Rho Int. J. Dev. Biol. (2007) 51: 85-90

Common culture conditions for maintenance and cardiomyocyte differentiation of the human embryonic stem cell lines, BG01 and HUES-7

Chris Denning, Cinzia Allegrucci, Helen Priddle, Maria D. Barbadillo-Muñoz, David Anderson, Tim Self, Nigel M. Smith, C. Tony Parkin and Lorraine E. Young Int. J. Dev. Biol. (2006) 50: 27-37

Dynamic distribution of the replacement histone variant $\mathrm{H} 3.3$ in the mouse oocyte and preimplantation embryos

Maria-Elena Torres-Padilla, Andrew J. Bannister, Paul J. Hurd, Tony Kouzarides and Magdalena Zernicka-Goetz

Int. J. Dev. Biol. (2006) 50: 455-461

The instability of the neural crest phenotypes: Schwann cells can differentiate into myofibroblasts

Carla Real, Corinne Glavieux-Pardanaud, Pierre Vaigot, Nicole Le Douarin and Elisabeth Dupin

Int. J. Dev. Biol. (2005) 49: 151-159

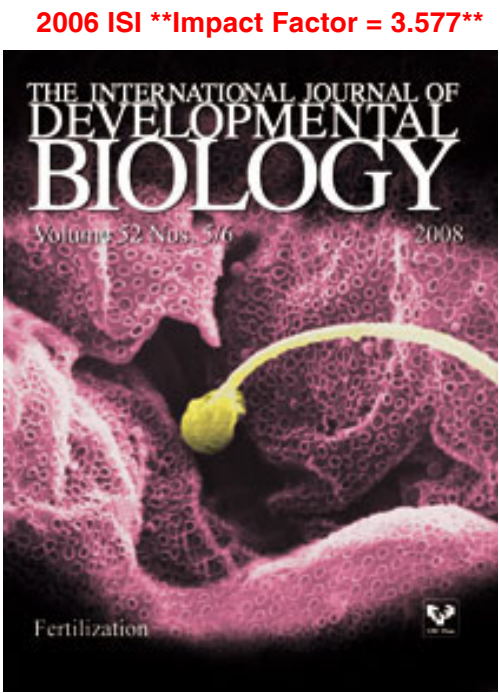

